\title{
Implementasi Rekrutmen dan Seleksi Perangkat Desa
}

(Seri Pengabdian Masyarakat di Desa Kumpulrejo Bojonegoro Jawa Timur)

\author{
${ }^{1}$ Sugeng Mashudi, ${ }^{2}$ Aliyadi, ${ }^{3}$ Ismail Abdurrozzaq, ${ }^{4}$ Elisia Kumalasari, ${ }^{5}$ Fitayani I.P. \\ Fakultas Ilmu Kesehatan ${ }^{1}$, Fakultas Teknik ${ }^{2,3,4,5}$ \\ Univeritas Muhammadiyah Ponorogo \\ *Email: sugengmashudi@umpo.ac.id
}

\begin{abstract}
ABSTRAK
Pelaksanaan pengabdian masyarakat (PKM) ini bertujuan untuk melaksanakan analisis dan mendeskripsikan pelaksanaan rekrutmen dan seleksi perangkat desa di Desa Kumpulrejo Kabupaten Bojonegoro Jawa Timur. Berdasarkan hasil FGD, dapat ditemukan ada dua permasalahan yang dihadapi oleh mitra yakni: pertama, mitra belum mampu menyusun soal standar tes perangkat desa; kedua, desa belum mampu melakukan analisis jawaban peserta ujian perangkat desa. Oleh karena itu, solusi yang ditawarkan tim pengabdian kepada mitra adalah melaksanakan pengimplementasian tentang rekrutmen dan seleksi perangkat desa tersebut. Metode yang digunakan adalah metode advokasi yakni pendampingan masyarakat dalam menyelesaikan persoalan yang sedang dihadapi bersama-sama dengan pemegang kebijakan di wilayah tersebut. Hasil PKM menunjukkan bahwa implementasi rekrutmen dan seleksi aparat desa di desa di Desa Kumpulrejo Kabupaten Bojonegoro Jawa Timur telah dilakukan sesuai dengan ketentuan dimana proses registrasi dan seleksi dilakukan setiap desa dan proses seleksi secara offline. Pelaksaan tes dengan bentuk soal pilihan ganda dan uraian dengan jumlah masing-masing 80 dan 20 soal. Hasil seleksi menunjukkan bahwa peserta dengan nilai tertinggi pada masing-masing lowongan dengan batas minimal 60 berhak untuk dipromosikan sebagai pamong Desa. Pelaksanaan PKM berupa seleksi perangkat Desa Kumpulrejo Kecamatan Kapas telah dilaksanakan dengan mengedepankan keterbukaan dan pertanggungjawaban. Kemajuan desa akan terwujud dengan adanya perangkat desa yang berkualitas.
\end{abstract}

Kata Kunci: rekrutmen, Kumpulrejo, Bojonegoro.

\begin{abstract}
Recruitment and selection of village officials. The method used is the advocacy method, namely community assistance in solving problems that are being faced together with policyholders in the region. The PKM results show that the implementation of recruitment and selection of village officials in the village in Kumpulrejo Village, Bojonegoro Regency, East Java has been carried out in accordance with the provisions where the registration and selection process is carried out in each village and the selection process is offline using a computer. Implementation of the test in the form of multiple-choice questions and descriptions with a total of 80 and 20 questions, respectively. The election results show that the participants with the highest score on each vacancy with a minimum limit of 60 are entitled to be promoted as civil servants. The PKM implementation in the form of a selection of apparatus in the Kumpulrejo Village, Kapas District, has been carried out by promoting openness and accountability. Village progress will be realized with the existence of quality village officials.
\end{abstract}




\section{PENDAHULUAN}

Penyelenggaraan seleksi perangkat desa akan memberikan kesempatan desa untuk mandiri dalam menentukan kualitas perangkat desa. Desa sebagai salah satu bagian terpenting dalam pelaksanaan desentralisasi dandemokratisasi di daerah (Aritonang, D. M. (2018). Tanpa adanya perangkat desa pelayanan terhadap masyarakat akan terhambat (Aringga, R. D. 2017). Desentralisasi Indonesia akan memberi ruang bagi pemerintah daerah khususnya desa berkesempatan menyelenggarakan otonomi dearah, khususnya seleksi perangkat desa.

Desa Kumpulrejo adalah salah satu desa yang berada di Kecamatan Kapas, Kabupaten Bojonegoro, Jawa Timur, Indonesia. Secara geografis Desa kumpulrejo sebelah utara berbatasan dengan Desa Tanjungharjo, sebelah Timur berbatasan dengan Kecamatan Sukosewu, sebelah Selatan berbatasan dengan Kecamatan Bader dan sebelah barat Berbatasan dengan Desa Bendo.

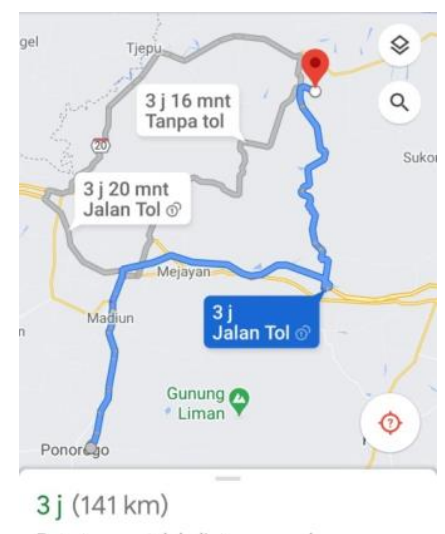

Gambar 1 Peta arak Mitra dengan Kampus penyelenggara

Secara historis Desa Kumpulrejo merupakan desa yang terbentuk dari Transmigran lokal, hingga saat ini jumlah jumlah RT sebanyak 5 RT. Jarak tempat PKM dengan Universitas Muhamamdiya Ponorogo sejauh $141 \mathrm{KM}$ dengan waktu tempuh perjalanan selama sekitar 3 jam seperti terlihat pada Gambar 1.

Potensi desa Kumpulrejo sebagia besar berasal dari pertanian. Berbagai tanaman dapat tumbuh di desa Kumplrejo, selain polowijo potensi yang bisa diandalkan masyarakat desa Kumpulrejo adalah Waluh (labu kuning). Pada Vestifal Waluh tahun 2017 dengan memanfaatkan Potensi waluh, dodol waluh seperti terlihat pada Gambar 2.

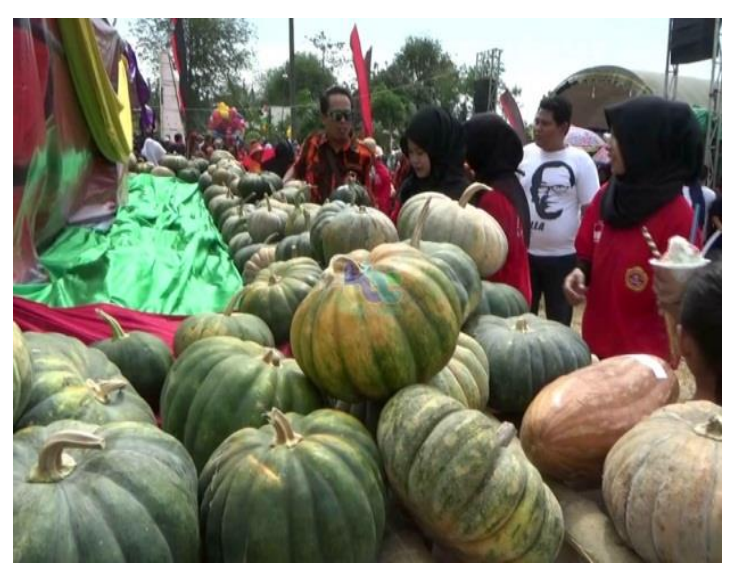

Gambar 2 Festifal Waluh di Desa Kumpulrejo

Berdasarkan hasil FGD dengan Mitra menunjukkan bahwa 1) mitra belum mampu menyusun soal standar tes perangkat desa; 2) desa belum mampu melakukan analisis jawaban peserta ujian perangkat desa.

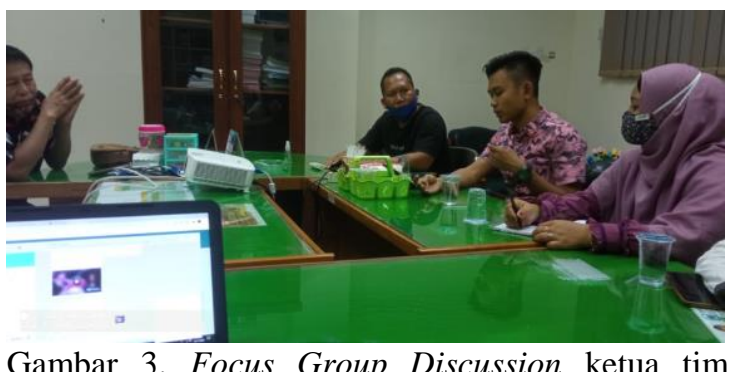

Gambar 3. Focus Group Discussion ketua tim pelaksana kegiatan (nomor 2 dari kanan) dengan ketua pengabdi (paling kiri)

Menimbang persoalan yang terjadi pada mitra, solusi yang ditawarkan oleh tim pengabdian adalah bantuan pendampingan pelaksanaan rekrutmen dan seleksi perangkat desa. Pelaksanaan PKM 
ini bertujuan untuk menganalisis dan mendeskripsikan pelaksanaan rekrutmen dan seleksi perangkat desa di Desa Kumpulrejo Kabupaten Bojonegoro Jawa Timur.

Tabel 1. Analisis Situasi

\begin{tabular}{|l|l|l|l|}
\hline No & Bidang & Permasalahan & Solusi \\
\hline 1 & $\begin{array}{l}\text { Pengad } \\
\text { aan soal } \\
\text { standart }\end{array}$ & $\begin{array}{l}\text { Mitra belum } \\
\text { mampu } \\
\text { membuat soal } \\
\text { tes yang } \\
\text { standart }\end{array}$ & $\begin{array}{l}\text { FGD dan } \\
\text { Aplikasi } \\
\text { pembuata } \\
\text { n soal } \\
\text { oleh TIM } \\
\text { PKM }\end{array}$ \\
\hline 2 & $\begin{array}{l}\text { Evaluas } \\
\text { i tes }\end{array}$ & $\begin{array}{l}\text { Mitra belum } \\
\text { mampu } \\
\text { melakukan } \\
\text { evaluasi atas tes } \\
\text { perangkat }\end{array}$ & $\begin{array}{l}\text { FGD dan } \\
\text { Kerjasam } \\
\text { a dengan } \\
\text { tim PKM }\end{array}$ \\
\hline
\end{tabular}

\section{RUMUSAN MASALAH}

Berdasarkan latar belakang dan analisis situasi, dapat dirumuskan permasalahan yaitu bagaimanakah implementasi rekrutmen dan seleksi perangkat di Desa Kumpulrejo Bojonegoro?.

\section{METODE}

Metode yang digunakan untuk menyelesaikan permasalahan mitra adalah metode advokasi. Metode advokasi merupakan usaha untuk mempengaruhi kebijakan melalui bermacam-macam bentuk komunikasi persuasif dengan menggunakan informasi yang akurat dan tepat (Slavin, RE., Hopkins, J. 2009). Metode Advokasi yang dilakukan TIM PKM berupa pendampingan dalam evaluasi tes seleksi dan pembuatan soal ujian standar oleh TIM PKM. Metode advokasi digunakan untuk mendampingi pemerintah Desa Kumpulrejo berupa persiapan dan evaluasi pelaksanaan tes perangkat desa.

\section{PEMBAHASAN}

Pelaksanaan kegiatan PKM berada di Desa Kumpulrejo, desa di wilayah
Kecamatan Kapas, Kabupaten Bojonegoro, Jawa Timur. Kegiatan berupa Ujian Seleksi Perangkat Desa untuk mengisi kekosongan perangkat desa (Perades) yang bertempat di Pendopo Desa setempat secara umum telah terlaksana dengan baik.

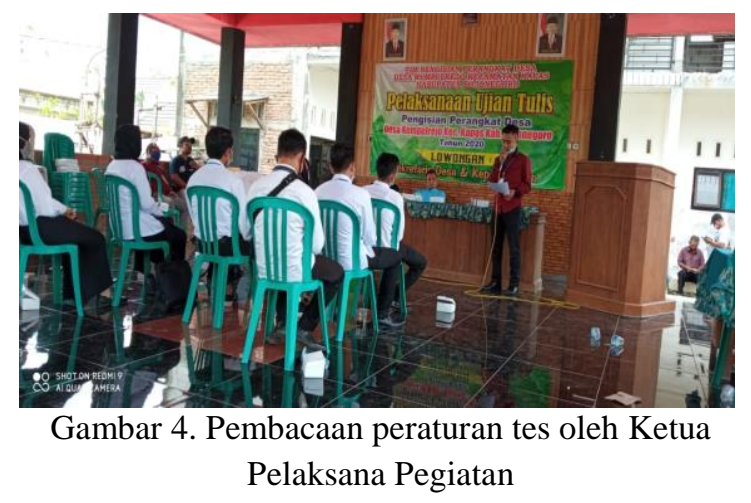

Panitia mempercayakan proses seleksi ini dengan menggandeng Universitas Muhammadiyah Ponorogo (TIM PKM) sebagai pihak ketiga dalam proses ujian tulis rekrutmen tersebut. Formasi lowongan Desa Kumpulrejo yakni Kepala Dusun, dan Sekretaris Desa yang diikuti 8 peserta diantaranya 5 Sekdes dan 3 Kasun. Ketua Panitia Seleksi Desa Kumpulrejo Kecamatan Kapas mengaku mengedepankan keterbukaan dan pertanggung jawaban dalam rekrutmen ini. "Kita berusaha terbuka, transparan dan akuntabel, kita tetap mengedepankan akuntabilitas dan kerahasiaan dalam rekrutmen ini," tegas Ketua Panitia ini. Rudi juga menunjukkan keterbukaan dengan proses ujian yang tengah berjalan, mulai test tulis, pemeriksaan hasil ujian tulis manual hingga pengumuman yang dilakukan oleh pihak ketiga.

Tabel 2. Hasil tes seleksi pamong Desa Kumpulrejo

\begin{tabular}{|l|l|l|l|l|}
\hline No & $\begin{array}{l}\text { Calon } \\
\text { Sekdes } \\
\text { (SK)/Kasun } \\
(\mathrm{KS})\end{array}$ & Nilai & $\begin{array}{c}\text { Batas } \\
\text { Lulus }\end{array}$ & $\begin{array}{c}\text { Ketera } \\
\text { ngan }\end{array}$ \\
\hline 1 & $\begin{array}{l}\text { Sdr JAP } \\
(\mathrm{SK})\end{array}$ & 97 & 60 & Lulus \\
\hline 2 & $\begin{array}{l}\text { Sdr DAP } \\
(\mathrm{SK})\end{array}$ & 57,25 & 60 & $\begin{array}{l}\text { Tidak } \\
\text { Lulus }\end{array}$ \\
\hline 3 & $\begin{array}{l}\text { Sdr } \quad \text { AS } \\
(\mathrm{SK})\end{array}$ & 54,75 & 60 & $\begin{array}{l}\text { Tidak } \\
\text { Lulus }\end{array}$ \\
\hline
\end{tabular}




\begin{tabular}{|l|ll|l|l|l|}
\hline 4 & $\begin{array}{l}\text { Sdr } \\
(\mathrm{SK})\end{array}$ & FS & 38,75 & 60 & $\begin{array}{l}\text { Tidak } \\
\text { Lulus }\end{array}$ \\
\hline 5 & $\begin{array}{l}\text { Sdr } \\
(\mathrm{SK})\end{array}$ & NI & 28,25 & 60 & $\begin{array}{l}\text { Tidak } \\
\text { Lulus }\end{array}$ \\
\hline 6 & $\begin{array}{l}\text { Sdr. } \\
(\mathrm{KS})\end{array}$ & MUP & 96 & 60 & Lulus \\
\hline 7 & $\begin{array}{l}\text { Sdr. } \\
(\mathrm{KS})\end{array}$ & DS & 39,25 & 60 & $\begin{array}{l}\text { Tidak } \\
\text { Lulus }\end{array}$ \\
\hline 8 & $\begin{array}{l}\text { Sdr } \\
(\mathrm{KS})\end{array}$ & MAR & 34,5 & 60 & $\begin{array}{l}\text { Tidak } \\
\text { Lulus }\end{array}$ \\
\hline
\end{tabular}

Hasil PKM menunjukkan bahwa implementasi rekrutmen dan seleksi aparat desa di desa di Desa Kumpulrejo Kabupaten Bojonegoro Jawa Timur telah dilakukan di sesuai dengan ketentuan dimana proses registrasi dan seleksi dilakukan setiap desa dan proses seleksi secara offline menggunakan komputer. Pelaksaan tes dengan bentuk soal pilihan ganda dan uraian dengan jumlah masingmasing 80 da 20 soal. Hasil seleksi menunjukkan bahwa peserta dengan nilai tertinggi pada masing-masing lowongan dengan batas minimal 60 berhak untuk dipromosikan sebagai pamong Desa.

Pelaksanaan PKM berupa seleksi perangkat Desa Kumpulrejo Kecamatan Kapas telah dilaksanakan dengan mengedepankan keterbukaan dan pertanggungjawaban. Seleksi yang mengedepankan keterbukaan dan pertanggungjawaban akan menghasilkan pamong desa yang berkualitas. Kemajuan desa akan terwujud dengan adanya perangkat desa yang berkualitas. Desa dengan lowongan Perlu dilakukan tes perangkat desa dengan tetap mengedepankan keterbukaan dan pertanggungjawaban. Pendidikan terakhir, pengalaman kerja, ujian tertulis dan wawancara kriteria yang telah ditentukan oleh pihak kantor kepala desa (Puspa, M. A. 2019).

Setelah dilakukan pemeriksaan manual, segera panitia mengumumkan hasilnya secara terbuka kepada seluruh peserta yang masih menunggu (Wartaku, 2020). Dengan jumlah 8 peserta masih dimungkinkan untuk dikoreksi secara manual, namun jika jumlah yang di tes lebih dari 50 peserta pengabdi akan memerlukan waktu lebih banyak sehingga pengumuman peserta lolos akan lebih lambat. Oleh karena itu, perlu dibuat ujian sistem Computer Assisted Test (CAT). Selain lebih cepat dalam evaluasi test sistem CAT tetap mempertahankan objektifitas dalam evaluasi kegiatan tes pamong desa.

\section{SIMPULAN}

Pelaksanaan PKM berupa seleksi perangkat Desa Kumpulrejo Kecamatan Kapas telah dilaksanakan dengan mengedepankan keterbukaan dan pertanggungjawaban. Seleksi yang mengedepankan keterbukaan dan pertanggungjawaban akan menghasilkan pamong desa yang berkualitas. Kemajuan desa akan terwujud dengan adanya perangkat desa yang berkualitas.

Desa dengan lowongan perangkat perlu dilakukan tes perangkat desa dengan tetap mengedepankan keterbukaan dan pertanggungjawaban dengan system manual maupun CAT.

\section{UCAPAN TERIMA KASIH}

Terima kasih kami ucapkan kepada LPPM Universitas Muhammadiyah Ponorogo yang telah memberikan kesempatan untuk melaksanakan pengabdian masyarakat di Desa Kumpulrejo.

\section{DAFTAR PUSTAKA}

Aringga, R. D. (2017). Sistem Pendukung Keputusan Menggunakan Metode Simple Additive Weighting Dalam Pengolahan Seleksi Perangkat Desa Baru (Studi Kasus: Kecamatan Mojo-Kabupaten Kediri). JATI (Jurnal Mahasiswa Teknik Informatika), 1(1), 238-289.

Aritonang, D. M. (2018). Kebijakan Desentralisasi Untuk Desa Dalam Undang-Undang Nomor 6 Tahun 
2014 Tentang Desa Decentralization Policy For Village In Law Number 6 Of 2014 On Village. Jurnal Indonesia, 12(3).

Beritabojonegoro. 2017. Festifal Waluh, Ajang Promosi Potensi Desa. Beritabojonegoro.com. Diakses pada 27 November 2020.

Wartaku. 2020. Inilah hasil ujian perangkat desa kumpulrejo kecamatan kapas. https://wartaku.id/pemerintahan.

Diakses 27 November 2020

Puspa, M. A. (2019). Implementasi Data Mining Klasifikasi Algoritma C4. 5 Dalam Perekrutan Perangkat Desa. Building of Informatics, Technology and Science (BITS), 1(2), 92-97.

Slavin, RE., Hopkins, J. 2009. A Practical Guide to Cooperative Learning. Allyn and Bacon. USA 